\title{
SOSIAL, BUDAYA SERTA PENGETAHUAN IBU HAMIL YANG TIDAK MENDUKUNG KEHAMILAN SEHAT
}

\author{
Rina Doriana Pasaribu, Tria Feni Setia, Lusiana Gultom \\ Jurusan Kebidanan Poltekkes Kemenkes Medan
}

\begin{abstract}
Abstrak
Sosial dan budaya kehamilan merupakan faktor tidak langsung penyumbang angka kematian ibu.Tingkat kurangnya pengetahuan ibu hamil juga menjadi faktor lainnya.Dalam Survei Demografi dan Kesehatan Indonesia (SDKI) tahun 2012 AKI di Indonesia yaitu mencapai 359 per 100 ribu kelahiran.Penelitian ini bertujuan untuk mengetahui gambaran sosial dan budaya serta pengetahuan ibu hamil tentang kehamilan di Desa Percut Kecamatan Percut Sei Tuan Kabupaten Deli Serdang Tahun 2014. Penelitian bersifat deskriptif dengan data primer.Populasi penelitian adalah semua ibu hamil di Desa Percut Kecamatan Percut Sei Tuan Kabupaten Deli Serdang Tahun 2014 pada bulan Mei sampai Juni 54 ibu hamil.Pengambilan sampelnya dengan teknik total populasi. Dari hasil penelitian dari segi sosial umumnya ibu hamil berinteraksi dengan suami dan tetangga $(100 \%)$, orang tua $(27,77 \%)$,mertua $(12,96 \%)$,bidan $(11,11 \%)$,sesama ibu hamil $(9,25 \%)$.Interaksi Ibu hamil saat ada keluhan memiliki persentase dengan suami(100\%),orang tua $(18,51 \%)$,mertua dan tetangga $(9,25 \%)$ bidan $(12,96 \%)$,interaksi terdekat ibu hamil dengan suami $(100 \%)$,orang tua $(22,22 \%)$ mertua dan bidan $(5,55 \%)$. sumber nasehat saat hamil bersumber dari mertua $(62,96 \%)$,orang tua $(53,70 \%)$ tetangga $(37,30 \%)$.dari segi budaya umumnya ibu hamil memiliki kepercayaan berpantang makan, perilaku, mengikuti nasehat saat hamil,melaksanakan upacara kehamilan.Berdasarkan pengetahuan ibu hamil berpengetahuan kurang $(68,51 \%)$, berpengetahuan baik $(7,41 \%)$ dan cukup $(24,08 \%)$. Disarankan bagi kepala desa agar meningkatkan kesehatan ibu hamil dengan bekerjasama dengan bidan dan melakukan pendekatan melalui orang terdekat ibu hamil.
\end{abstract}

Kata kunci : Sosial, Budaya, Pengetahuan, Ibu Hamil

\section{PENDAHULUAN}

Indonesia sehat adalah suatu gambaran kondisi Indonesia di masa depan, yakni masyarakat, bangsa, dan negara yang ditandai oleh penduduknya hidup dalam lingkungan dengan perilaku hidup sehat, memiliki kemampuan menjangkau pelayanan kesehatan yang bermutu secara adil dan merata, serta mencapai derajat kesehatan yang setinggi-tingginya di seluruh wilayah Negara Kesatuan Republik Indonesia (NKRI). Visi Depkes 2010-2014 yaitu masyarakatsehat yang mandiri dan berkeadilan (Depkes, 2010).Setiap negara memiliki tolak ukur dalam pencapaian derajat kesehatan, diIndonesia salah satu indikator dalam pencapaian derajat kesehatan masyarakat sehat yang mandiri dan berkeadilan sesuai dengan visi Depkes 2010 - 2014 adalah dengan target menurunkan kematian Ibu (AKI) dan angka kematian bayi (AKB) yang masih tinggi (Ronald, 2011).

World Health Organization (WHO) memperkirakan angka kematian maternal di Indonesia diperkirakan mencapai 100 sampai 1.000 lebih per 100.000 dari kelahiran hidup.Hasil laporan kemajuan pencapaian Millennium Development Goals (MDGs) tahun 2007 Angka Kematian Ibu (AKI) di Indonesia masih mencapai 307 per 100.000 kelahiran hidup, tertinggi di Asia Tenggara (Sukowati, 2008). Dan berdasarkan Survei Demografi dan Kesehatan Indonesia (SDKI) pada tahun
2012 jumlah AKI di Indonesia yaitu 359 per 100 ribu kelahiran hidup (Depkes, 2012). Berdasarkan laporan dari profil kab/kota AKI maternal yang dilaporkan di Sumatera Utara tahun 2012 yaitu 106/100.000 kelahiran hidup.(Profil Kesehatan Sumatera Utara Tahun 2012)

Diperkirakan 50.000 .000 ibu setiap tahunnya mengalami masalah kesehatan yang berhubungan dengan komplikasi - komplikasi kehamilan, persalinan dan nifas.komplikasi yang ada kaitannya dengan kehamilan berjumlah sekitar $18 \%$ dari jumlah global penyakit yang di derita wanita pada usia reproduksi. Dan diperkirakan $40 \%$ wanita hamil akan mengalami komplikasi sepanjang kehamilannya (Ronald, 2011). Menurut Ronald (2010) diperkirakan dari setiap ibu yang meninggal dalam kehamilan, karena menderita komplikasi, diakibatkan karena adanya penyebab langsung dan tidak langsung dari kematian ibu tersebut. Penyebab utama kematian ibu yaitu adanya perdarahan $(25 \%)$, sepsis $(15 \%)$, hipertensi dalam kehamilan (12\%), partus macet (8\%), komplikasi aborsi tidak aman (13\%), dan penyebab lain $(8 \%)$ maka penyebab tidak langsung dari kematian ibu seperti anemia. Sebab kematian ibu , mulai dari kehamilan itu sendiri terdapat banyak masalah yang salah satunya kehamilan dengan mitos - mitos yang baik sadar atau tidak disadari selalu hidup secara turun temurun dalam masyarakat. Mitosmitos kehamilan ini dapat memberikan pengaruh bagi perilaku ibu hamil baik itu positif maupun negatif hingga 
mempengaruhi kunjungan pemeriksaan kehamilan.

Berdasarkan Profil Kesehatan Sumatera Utara Tahun 2012 Cakupan pemeriksaan kehamilan ibu hamil di Sumatera Utara sejak tahun 2007 mengalami kenaikan dari 77,95\% menjadi 85,92\% ditahun 2012, yaitu untuk cakupan KI sebesar 92,74 \% dan untuk cakupan K4 sebesar 85,92 \% dari 25 kabupaten dan 8 kota yang ada di Sumatera Utara namun peningkatan ini terkesan lambat karena peningkatkannya hanya sekitar $2 \%$ setiap tahun. Dengan peningkatan seperti ini dikhawatirkan Sumatera Utara tidak mampu mencapai target SPM bidang kesehatan yaitu 95\% di tahun 2015.

Dari penyebab kematian ibu tersebut masalah kematian maupun kesakitan dan kunjungan pemeriksaan kehamilan pada ibu tidak terlepas dari faktor sosial budaya dan lingkungan di dalam masyarakat.Disadari atau tidak,faktor kebudayaan, kepercayaan dan pengetahuan budaya seperti berbagai pantangan, hubungan sebab akibat, antara makanan dan kondisi sehat sakit, kebiasaan, dan ketidaktahuan, seringkali membawa dampak positif maupun negatif terhadap kesehatan ibu.

Pengetahuan, sosial dan budaya ibu yang sedang hamil akan memengaruhi kesehatan ibu saat hamil. Berdasrkan latar belakang tersebut penelitian ini dilakukan untuk mengetahui gambaran pengetahuan, sosial dan budaya ibu hamil di Desa Percut Kecamatan Percut Sei Tuan Kabupaten deli Serdang.

\section{Perumusan Masalah}

Permasalahan dalam penelitian ini yaitu " Bagaimanakah gambaran sosial, budaya serta pengetahuan ibu hamil tentang kehamilan di desa Percut Kecamatan Percut Sei Tuan Kabupaten Deli Serdang tahun 2014 “

\section{Tujuan Penelitian}

Penelitian ini bertujuan untuk mengetahui gambaran sosial dan budaya serta pengetahuan ibu hamil tentang kehamilan di Desa Percut Kecamatan Percut Sei Tuan Kabupaten Deli Serdang tahun 2014

\section{METODE PENELITIAN}

\section{Jenis Penelitian}

Penelitian ini bersifat deskriftif yaitu suatu metode penelitian yang dilakukan dengan tujuan utama untuk membuat gambaran tentang suatu keadaan untuk mengetahui Gambaran Sosial Budaya dan Pengetahuan Ibu
Hamil Tentang Kehamilan Di Desa Percut Kecamatan Percut Sei Tuan Kabupaten Deli Serdang Tahun 2014.

\section{Lokasi Penelitian dan Waktu Penelitian}

Penelitian ini dilakukan di Desa Percut Kecamatan Percut Sei Tuan Kabupaten Deli Serdang pada bualan Januari - Mei 2014.

\section{Populasi Dan Sampel Penelitian}

Populasi dalam penelitian ini adalah seluruh Ibu hamil yang ada di Desa Percut Kabupaten Deli Serdang sebanyak 54 orang ibu hamil pada bulan Januari sampai April tahun 2014 dan seluruh populasi dijadikan sebagai sampel.

\section{Metode Pengumpulan Data}

Metode pengumpulan data dengan cara mengambil data secara primer yaitu data yang langsung di peroleh peneliti sendiri melalui kuesioner. Tipe kuesioner yang digunanakan dengan kuesioner semi terbuka untuk sosial dan budaya ibu hamil serta kuesioner tertutup untuk pengetahuan ibu hamil Pengambilan data di lakukan dengan melakukan kunjungan rumah.

\section{Pengolahan Data dan analisa Data}

Data yang terkumpul selanjutnya diediting dan ditabulating. Data dianalisis dengan melihat persentase (distribusi frekuensi) dari masing-masing variabel yang diteliti, kemudian dibahas dengan menggunakan teori dan kepustakaan yang ada

\section{HASIL PENELITIAN DAN PEMBAHASAN}

\section{Gambaran Wilayah Penelitian}

Wilayah penelitian berada di Desa Percut Kecamatan Percut Sei Tuan Kabupaten Deli Serdang yang terbagi 18 dusun dalam satu dusun Desa Percut, terletak di sebelah barat dari wilayah Kecamatan Percut Sei Tuan Kabupaten Deli Serdang dengan mayoritas $90 \%$ penduduk bersuku Melayu tersebar di dalam 18 dusun,dan memiliki 1 puskesmas pembantu terletak di depan kantor kepala Desa Percut sementara untuk wilayah kerja puskesmas induk yang menaungi Desa Percut terletak di Desa Tanjung Rejo,yang memiliki jarak tempuh 15 menit dari Desa Percut.

\section{Karasteristik Responden}

\begin{tabular}{lcc} 
& Tabel 1. Distribusi Karasteristik Responden \\
\hline Gravida & Jumlah & Persen (\%) \\
\hline Primigravida & $\mathbf{2 8}$ & $\mathbf{5 1 , 8 5}$ \\
Secundygravida & $\mathbf{1 5}$ & $\mathbf{2 7 , 7 7}$ \\
Multigravida & 11 & $\mathbf{2 0 , 3 7}$ \\
\hline Total & $\mathbf{5 4}$ & $\mathbf{1 0 0}$ \\
\hline Usia Kehamilan & & $\mathbf{3 7 , 0 3}$ \\
\hline Trimester I & $\mathbf{2 0}$ & $\mathbf{2 5 , 9 2}$ \\
Trimester II & $\mathbf{1 4}$ & $\mathbf{3 7 , 0 3}$ \\
Trimester III & $\mathbf{2 0}$ & $\mathbf{1 0 0}$ \\
\hline Total & $\mathbf{5 4}$ & \\
\hline
\end{tabular}




\begin{tabular}{lcc} 
Jumlah Kunjungan ANC & & \\
\hline Pemeriksaan 1 x & 8 & 14,81 \\
Pemeriksaan $2 \times$ & 8 & 14,81 \\
Pemeriksaan 3 x & 4 & 7,40 \\
Pemeriksaan 4 x atau & 2 & 3,70 \\
lebih & & \\
Tidak ANC & 32 & 59,25 \\
\hline Total & 54 & 100 \\
\hline
\end{tabular}

2. LingkunganSosial Ibu Hamil di Desa Percut Kecamatan Percut Sei Tuan Kabupaten Deli Serdang Tahun 2014

Tabel 2. Distribusi Interaksi Sosial Sehari - hari Ibu Hamil Saat Hamil di Desa Percut Kecamatan Percut Sei Tuan Kabupaten Deli Serdang Tahun 2014

\begin{tabular}{clccc}
\hline No & Interaksi Sosial & Jumlah & N & Persen ( \%) \\
\hline 1 & Suami & $\mathbf{5 4}$ & $\mathbf{5 4}$ & $\mathbf{1 0 0}$ \\
$\mathbf{2}$ & Orang Tua & $\mathbf{1 5}$ & $\mathbf{5 4}$ & $\mathbf{2 7 , 7 7}$ \\
$\mathbf{3}$ & Mertua & 7 & $\mathbf{5 4}$ & $\mathbf{1 2 , 9 6}$ \\
$\mathbf{4}$ & Tetangga & $\mathbf{5 4}$ & $\mathbf{5 4}$ & $\mathbf{1 0 0}$ \\
$\mathbf{5}$ & Bidan & $\mathbf{6}$ & $\mathbf{5 4}$ & $\mathbf{1 1 , 1 1}$ \\
$\mathbf{6}$ & Sesama Ibu Hamil & $\mathbf{5}$ & $\mathbf{5 4}$ & $\mathbf{9 , 2 5}$ \\
\hline
\end{tabular}

Tabel 3. Distribusi Interaksi Ibu Hamil Jika ada Keluhan Saat Hamil di Desa Percut Kecamatan Percut Sei Tuan Kabupaten

\begin{tabular}{clccc}
\multicolumn{5}{c}{ Deli Serdang Tahun 2014} \\
\hline No & Interaksi Ibu Saat Ada Keluhan & Jumlah & N & Persen (\%) \\
\hline $\mathbf{1}$ & Suami & $\mathbf{5 4}$ & $\mathbf{5 4}$ & $\mathbf{1 0 0}$ \\
$\mathbf{2}$ & Orang Tua & $\mathbf{1 0}$ & $\mathbf{5 4}$ & $\mathbf{1 8 , 5 1}$ \\
$\mathbf{3}$ & Mertua & $\mathbf{5}$ & $\mathbf{5 4}$ & $\mathbf{9 , 2 5}$ \\
$\mathbf{4}$ & Tetangga & $\mathbf{5}$ & $\mathbf{5 4}$ & $\mathbf{9 , 2 5}$ \\
$\mathbf{5}$ & Bidan & $\mathbf{7}$ & $\mathbf{5 4}$ & $\mathbf{1 2 , 9 6}$ \\
\hline
\end{tabular}

Tabel 4. Distribusi Sumber Nasehat Pantangan /Anjuran ke Ibu Hamil di Desa Percut Kecamatan Percut Sei Tuan Kabupaten Deli Serdang Tahun 2014

\begin{tabular}{llccc}
\hline No & Sumber Nasehat & Jumlah & N & Persen ( \% ) \\
\hline & & & & \\
1 & Orang Tua & $\mathbf{2 9}$ & $\mathbf{5 4}$ & $\mathbf{5 3 , 7 0}$ \\
$\mathbf{2}$ & Mertua & $\mathbf{3 4}$ & $\mathbf{5 4}$ & $\mathbf{6 2 , 9 6}$ \\
$\mathbf{3}$ & Tetangga & $\mathbf{2 0}$ & $\mathbf{5 4}$ & $\mathbf{3 7 , 3 0}$ \\
& & & & \\
\hline
\end{tabular}

3. Budaya Berpantang Makan Ibu Hamil Di Desa Percut Kecamatan Percut Sei Tuan Kabupaten Deli Serdang Tahun 2014

Tabel 5. Distribusi Berpantang Makan Ibu Hamil Di Desa Percut Kecamatan Percut Sei Tuan Kabupaten Deli Serdang Tahun 2014

\begin{tabular}{|c|c|c|c|c|}
\hline No & Budaya Berpantang Makan & Jumlah (f) & $\mathbf{N}$ & Persen $(\%)$ \\
\hline $\mathbf{1}$ & Makan Ketan & 13 & 54 & 24,07 \\
\hline 2 & Makan Kerak Nasi & 16 & 54 & 29,62 \\
\hline 3 & Makan Cabai Rawit & 16 & 54 & 29,62 \\
\hline 4 & $\begin{array}{l}\text { Makan Ikan di Usia > } 7 \\
\text { Bulan }\end{array}$ & 21 & 54 & 38,88 \\
\hline 5 & Makan Tape & 14 & 54 & 25,92 \\
\hline 6 & Makan Durian & 11 & 54 & 20,37 \\
\hline 7 & Makan Nenas & 11 & 54 & 20,37 \\
\hline 8 & Makan Jantung Pisang & 17 & 54 & 31,48 \\
\hline 9 & $\begin{array}{l}\text { Makan Banyak Di Usia >7 } \\
\text { Bulan }\end{array}$ & 12 & 54 & 22,22 \\
\hline
\end{tabular}


Tabel 6. Distribusi Berpantang Perilaku Ibu Hamil Di Desa Percut Kecamatan Percut Sei Tuan Kabupaten Deli Serdang Tahun 2014

\begin{tabular}{llccc}
\hline No & \multicolumn{1}{c}{ Budaya Berpantang Perilaku } & Jumlah & $\mathrm{N}$ & $\%$ \\
\hline 1 & Tidak boleh Melilitkan handuk dileher & $\mathbf{2 3}$ & $\mathbf{5 4}$ & $\mathbf{4 2 , 5 9}$ \\
2 & Tidak boleh gerai rambut selama & $\mathbf{1 7}$ & $\mathbf{5 4}$ & $\mathbf{3 1 , 4 8}$ \\
3 & hamil & & & \\
4 & Tidak boleh duduk di akar & $\mathbf{1 5}$ & $\mathbf{5 4}$ & $\mathbf{2 7 , 7 7}$ \\
5 & Tidak boleh mandi di atas jam 5 sore & $\mathbf{1 2}$ & $\mathbf{5 4}$ & $\mathbf{2 2 , 2 2}$ \\
6 & Tidak boleh makan di baskom & $\mathbf{6}$ & $\mathbf{5 4}$ & $\mathbf{1 1 , 1 1}$ \\
7 & Tidak keramas sore hari & $\mathbf{4}$ & $\mathbf{5 4}$ & $\mathbf{7 , 4 0}$ \\
8 & Tidak boleh keluar rumah malam hari & $\mathbf{2 6}$ & $\mathbf{5 4}$ & $\mathbf{4 8 , 1 4}$ \\
\hline
\end{tabular}

Tabel 7. Distribusi Nasehat Perilaku Ibu Hamil Di Desa Percut Kecamatan Percut Sei Tuan Kabupaten Deli Serdang Tahun

\begin{tabular}{llccc}
\multicolumn{1}{c}{2014} & & \\
\hline No & Budaya Berpantang Perilaku & Jumlah (f) & N & Persen (\%) \\
\hline & & & & \\
1 & Sering berjalan pagi & 7 & 54 & $\mathbf{1 2 , 9 6}$ \\
2 & Pakai paku saat keluar rumah & $\mathbf{2 6}$ & $\mathbf{5 4}$ & $\mathbf{4 8 , 1 4}$ \\
3 & Memakai gunting di pakaian ibu & $\mathbf{1 7}$ & $\mathbf{5 4}$ & $\mathbf{3 1 , 4 8}$ \\
4 & Minum minyak sayur waktu hamil tua & $\mathbf{2 5}$ & $\mathbf{5 4}$ & $\mathbf{4 6 , 2 9}$ \\
5 & Minum air kelapa & $\mathbf{1 4}$ & $\mathbf{5 4}$ & $\mathbf{2 5 , 9 2}$ \\
6 & Mandi sebelum jam 5 sore & $\mathbf{9}$ & $\mathbf{5 4}$ & $\mathbf{1 6 , 6 6}$ \\
7 & Tidak boleh tidur di lantai & $\mathbf{1 0}$ & $\mathbf{5 4}$ & $\mathbf{1 8 , 5 1}$ \\
\hline
\end{tabular}

Tabel 8. Distribusi Upacara Adat Ibu Hamil Di Desa Percut Kecamatan Percut Sei Tuan Kabupaten Deli Serdang Tahun

\begin{tabular}{ccccc}
\multicolumn{5}{c}{2014} \\
\hline No & Upacara Hamil & Jumlah (f) & N & Persen (\%) \\
\hline 1 & Upacara hamil usia 4 bulan & $\mathbf{2 0}$ & $\mathbf{5 4}$ & $\mathbf{3 7 , 0 3}$ \\
$\mathbf{2}$ & Upacara hamil usia 7 bulan & $\mathbf{2 7}$ & $\mathbf{5 4}$ & $\mathbf{5 0}$ \\
$\mathbf{3}$ & Upacara kehamilan ganjil & $\mathbf{2 3}$ & $\mathbf{5 4}$ & $\mathbf{4 2 , 5 9}$ \\
\hline
\end{tabular}

Pengetahuan Ibu Hamil Tentang kehamilan Di Desa Percut kecamatan Percut Sei Tuan Kabupaten Deli Serdang Tahun 2014.

Tabel 9. Distribusi Pengetahuan Ibu Hamil Tentang Kehamilan di Desa Percut Kecamatn Percut Sei Tuan Kabupaten Deli

\begin{tabular}{cccc} 
& & Serdang Tahun 2014 & \\
\hline No & Pengetahuan & Jumlah $(\mathbf{f})$ & Persen $(\%)$ \\
\hline $\mathbf{1}$ & Baik & $\mathbf{4}$ & $\mathbf{7 , 4 1}$ \\
$\mathbf{2}$ & Cukup & $\mathbf{1 3}$ & $\mathbf{2 4 , 0 8}$ \\
$\mathbf{3}$ & Kurang & $\mathbf{3 7}$ & $\mathbf{6 8 , 5 1}$ \\
\hline & Total & $\mathbf{5 4}$ & $\mathbf{1 0 0}$ \\
\hline
\end{tabular}

\section{Pembahasan}

\section{Interaksi Sosial Ibu Hamil}

Dari hasil penelitian tentang interaksi sosial ibu hamil mayoritas ibu hamil memiliki interaksi sosial dengan suami dan tetangga (100\%), sementara itu interaksi dengan orang tua $(27,77 \%)$ dengan mertua $(12,96 \%)$ dengan bidan $(11,11 \%)$ dengan sesama ibu hamil $(9,25 \%)$. Menurut Ana (2010) dukungan suami dalam kehamilan sangat penting dengan memberikan perwujudan dalam hal perhatian, dalam hal mendampingi ,merawat,menemani dan menjadi pihak yang membantu ibu dalam membuat keputusan bersama dan disebutkan juga bahwa dalam kehamilan di butuhkan orang lain seperti keluarga terdekat ataupun pihak lainnya yang sekiranya untuk turut membantu.

Hal ini sejalan dalam penelitian Fauziah tentang mitos kehamilan di Kecamatan Meurebo Kabupaten Aceh Barat Nanggroe Aceh Darussalam yang mengatakan bahwa interaksi sosial perempuan hamil sangat di perlukan dalam kesehariannya,baik berupa dukungan - dukungan psikologis,perhatian,kasih sayang,pengorbanan dan empati terutama dari pihak suami dan pihak keluarga- keluarga terdekat pada perempuan hamil tersebut.Hal ini di tinjau dari segi psikologis, karena jika perempuan hamil akan mengalami perubahan kondisi fisik dan emosional yang cukup kompleks yang di sebabkan adanya perubahan hormon dan proses adaptasi terhadap penyesuaian pola hidup dengan proses kehamilan yang terjadi sehingga memerlukan dukungan dan perhatian orang - orang terdekatnya yaitu seperti dengan pihak suami dan pihak keluarga terdekat.

Menurut Wahit (2012) Interaksi sosial berlandaskan antara kelompok manusia dengan antara 
kelompok sebagai kesatuan dan yang sifatnya tidak menyangkut pribadi. Interaksi sosial antara kelompok kelompok manusia dapat terjadi di keluarga dan di masyarakat yang di dasarkan pada berbagai faktor yaitu adanya faktor imitasi,faktor sugesti,faktor identifikasi dan faktor simpati.

Saat ada keluhan tentang kehamilannya, ibu-ibu hamil berdasarkan hasil penelitian hanya 7 orang $(12,96 \%)$ yang berinteraksi dengan bidan. Ibu hamil malah lebih seang berinteraksi atau meminta nasehat dari orang tua ataupun mertuanya, padahal sumber informasi yang lebih baik di dapat dari Bidan (petugas Kesehatan). Kebiasaan berinteraksi dengan tetangga juga kemungkinan penyebab semakin berkembangnya mitos-mitos ataupun budaya yang tidak sesuai dengan kesehatan ibu hamil diyakini oleh ibu hamil itu sendiri. Rendahnya kunjungan antenatal $(59,25)$ yaitu persentase ibu hamil yang tidak pernah melakukan ANC kemungkinan juga dipengaruhi sistem interaksi di masyarakat yang menyakini informasi ataupun budaya yang dianut oleh teman/tetangga.

Dari hasil penelitian tentang orang terdekat ibu di ketahui bahwa dari 54 mayoritas ibu hamil memiliki interaksi terdekat dengan suami yaitu dengan persentase $100 \%$,dan selain itu terdekat ibu hamil lainnya dengan orang tua $22,22 \%$ dengan mertua dan bidan 5,55 \%. Dalam penelitian Shrimartini tahun 2011 tentang Perawatan Kehamilan dalam Prespektif Budaya Madura di Desa Tambak dan Desa Rapalaok Kecamatan Omben Kabupaten Sampang di katakan bahwa ibu hamil di Desa Tambak dan Desa Rapaloak saat hamil memiliki hubungan terdekat dengan pihak keluarga (suami,orang tua ,mertua,bibi ataupun saudara), tetangga.bahkan dalam mempersepsikan tindakan yang akan di ambil dalam memutuskan sesuatu hal seperti terkait dalam pemeriksaan kehamilan,ibu hamil menyatakan akan berembuk atau berdiskusi dulu dengan orang-orang terdekatnya. Selain itu dalam penelitian Chriswardani tahun 2007 tentang Faktor Sosial Budaya dalam Praktik Perawatan Kehamilan,Persalinan dan Pasca Persalinan di Kecamatan Bangsri Kabupaten Jepara menyatakan bahwa dalam kehamilan di masyarakat jawa faktor kekerabatan( suami,orang tua,nenek) menjadi orang terdekat ibu hamil yang memegang peranan penting dalam tindakan tindakan si ibu yang berkaitan dengan kehamilan sampai pasca persalinan baik dalam memberika nasehat maupun dalam mengambil keputusan.

Penelitian ini juga menunjukkan bahwa sumber nasehat pantangan/anjuran ibu hamil $62,96 \%$ bersumber lainnya dari orang tua $53,70 \%$ dan bersumber dari tetangga $37,30 \%$. Dalam teori wahit (2012) ada mengungkapkan bahwa dalam aspek seorang individu,keluarga,masyarakat dan kebubudayaan adalah aspek yang tidak dapat di pisahkan,lingkungan sosial merupakan lingkungan yang pertama kali dijumpai dalam hidup keluarga,dan dalam keluarga individu mengembangkan kapasitas pribadinya yang salah satunya mengenai kebudayaan,dan individu akan mengejawantahkan apa yang sudah di pelajari dan di sampaikan keluarganya begitu halnya dengan keadaan dalam masa kehamilan kebudayaan saat hamil yang bersumber oleh pihak keluarga akan teraplikasi di masyarakat.

Dalam penelitian Fauziah tentang Mitos Kehamilan mengungkapkan bahwa pantangan dan anjuran yang di peruntukkan ibu hamil banyak di sampaikan oleh orang tua ,mertua,tetangga ataupun kerabat bahkan ada ketakutan dari perempuan hamil jika tidak mempercayai pantangan dan anjuran yang telah di sampaikan.Dan dalam penelitian menyebutkan bahwa pesan - pesan selama hamil banyak di sampaikan oleh orang tua ataupun keluarga yang wajib dilaksanakan,seperti halnya pantangan-pantangan ataupun anjuran saat hamil,jika pantangan maupun anjuran tersebut tidak dilakukan masyarakat meyakini bahwa akan mendapat balsan yang buruk.

\section{Budaya Berpantang Makan dan Berperilaku Saat Hamil}

Hasil penelitian menunjukkan bahwa mayoritas ibu hamil berpantang makan ikan di usia > 7 bulan 38,88 $\%$,di ikuti dengan pantangan lainnya seperti berpantang makan jantung pisang 31,48 \%,berpantang makan kerak nasi dan cabai rawit 29,62 \%,makan tape 25,92 \%,makan ketan 24,07 \%,makan banyak di usia kehamilan tua 22,22 $\%$ dan berpantang makan durian dan nenas 20,37 \%. Dari wawancara dengan ibu hamil, mereka menyatakan bahwa berpantang makan ikan di usia $>7$ bulan dikhawatirkan jika bersalin atau nifas nanti darah yang keluar akan berbau amis,sementara dalam teori bahwa bau amis pada masa nifas itu di akibatkan dari masa transisi perubahan lochea yang terjadi karena adanya perubahan pada bagian desidua di rahim.dan alam teori Almatsier (2009) mengenai konsep dasar ilmu gizi mengungkapkan bahwa jika dilakukan pembatasan mengenai konsumsi ikan saat kehamilan yang merupakan sumber protein dapat mengakibatkan terjadi masalah pada pembentukan dan perkembangan janin saat kehamilan,sebenarnya kandungan protein itu dalam ikan memiliki kandungan nilai protein 16,0 dan ikan juga disebutkan memiliki sumber protein hewani yang mempunyai susunan asam amino yang paling sesuai dengan kebutuhan manusia.

Mengenai berpantang makanan durian dan tape ibu hamil mengatakan dapat membahayakan kehamilan dan hal ini sejalan dalam teori Rafi (2009) mengungkapkan durian dan tape memiliki kandungan alkohol yang menghasilkan panas tubuh sehingga berpotensi menimbulkan bahaya pada janin diantaranya dapat menyebabkan perdarahan atau keguguran.sementara untuk pantangan makan nanas yang di katakan dapat menyebabkan keguguran tidak sesuai dengan teori Rafi (2009) yang menyebutkan bahwa sebaiknya selama hamil sebenarnya bukan tidak boleh mengkonsumsi nanas tapi harus ada pembatasan konsumsi nanas yang dalam nanas itu mengandung asam yang berlebihan sehingga dapat memacu peningkatan kadar asam lambung.

Dalam penelitian lainnya Fauziah tentang mitos kehamilan ada mengungkapkan pantangan makanan bagi ibu hamil meliputi larangan makan makanan tajam seperti nenas ,di khawatirkan mengalami keguguran.tidak boleh meminum es bagi ibu hamil agar bayinya tidak besar ,larangan makan nasi kerak di khawatirkan akan 
berdampak tidak keluarnya plasenta atau ari - ari.

Selain pantangan terhadap makanan tertentu ada juga pantangan terhadap jumlah porsi makanan yang di konsumsi dalam penelitian Afiyah tahun 2008 di salah satu daerah di Jawa Barat ibu yang kehamilannya memasuki usia 8-9 bulan harus mengurangi makan agar bayi yang di kandung mudah di lahirkan.Hal yang sama juga di ungkapkan Nurpuji Utami tahun 2003 dalam penelitian Mulyaningrumdi di Sulawesi Selatan menemukan ada kepercyaan tentang makanan yang berlebih di usia hamil tua dapat menyebabkan anak menjadi lebih besar dan dapat memperlambat persalinan sehingga ibu hamil harus membatasi makanannya untuk menghindari kesulitan proses persalinan.

Dalam Wahit (2012) mengungkapkan bahwa pembatasan asupan gizi pada kehamilan memiliki dampak yang begitu besar,di masyarakat pembatasan mengenai gizi disebabkan adanya kepercayaan pantangan terhadap beberapa makanan yang sebenarnya sangat dibutuhkan wanita hamil. Hal ini juga menjadi salah satu faktor predisposisi terjadinya kasus anemia dan kasus kurang gizi pada ibu hamil terutama di pedesaan.

Hasil penelitian juga menunjukkan ibu hamil yang berpantang perilaku seperti ibu hamil dilarang keluar rumah pada malam hari 48,14 \%,sementara ada juga itu berpantang perilaku melilitkan handuk di leher 42,59 $\%$,gerai rambut selama hamil $31,48 \%$,duduk di akar 27,77 $\%$,mandi di atas jam 5 sore $22,22 \%$,duduk di dapan pintu $18,51 \%$,membunuh binatang $12,96 \%$ dan makan dari baskom $11,11 \%$ serta keramas di sore hari 7,40 \%. Ibu hamil juga menyakini larangan melilitkan handuk di leher karena dapat menyebabkan lilitan tali pusat,pada hal dalam teori Rafi (2009) menjelaskan bahwa penyebab terjadinya lilitan tali pusat sebenarnya bukan karena melilitkan handuk di leher tetapi penyebab terjadi lilitan tali pusat diduga disebabkan oleh aktivitas yang berlebih sehingga mengakibatkan hiperaktivitas gerakan bayi.

Begitu juga dengan pantangan perilaku mengenai pantang duduk di depan pintu karena dapat mempersulit persalinan hal ini tidak sesuai dengan Mochtar (2010) dan Rafi (2009) yang mengungkapkan bahwa mudah atau sulitnya persalinan ditentukan dari beberapa hal yaitu sebagai berikut: dari segi power,passage,passanger,psikis dan penolong serta keterampilan dalam proses persalinan bukan karena duduk di depan pintu bisa mempersulit persalinan.

Mayoritas ibu hamil mengikuti nasehat berperilaku pakai paku selama hamil saat keluar rumah 48,14 \% selain itu ada juga nasehat untuk minum minyak sayur waktu hamil tua 46,29\%,memakai gunting di pakaian ibu 31,48 $\%$,minum air kelapa $25,94 \%$,tidak boleh tidur di lantai $18,51 \%$,dan nasehat untuk serimg berjalan pagi sebanyak $12,96 \%$,mandi sebelum jam 5 sore 16,66 \%.

Dilihat dari penelitian Fauzia tentang Mitos kehamilan mengungkapkan dari narasumber ibu hamil/yang pernah hamil memberikan jawaban mengenai anjuran yang harus di lakukan meliputi anjuran perbanyak jalan di pagi hari,menyapu mengepel dan di usia kandungan 7 bulan di anjurkan untuk melakukan hubungan seksual sesering mungkun untuk memudahkan proses persalinan nanti.Fauzia juga mengungkapkan ada anjuran untuk memakai penangkal (seunangkai) di pinggang seperti tali atau gunting di pakaian yang di yakini sebagai penangkalmakhluk halus yang ingin menganggu.dan anjuran lain yakni bila hendak berpergian harus menyelipkan paku kecil di dalam rambut agar tidak di ganggu mahkluk halu. Menurut Supardan tahun 2008 suatu tradisi yang ada di masyarakat akan merujuk kepada pola perilaku atau kepercayaan yang telah menjadi bagian dari suatu budaya yang telah lama di kenal kepercayaan secara turun menurun yang secara sosial diwariskan dari atu generasi ke generasi berikutnya.

\section{Pengetahuan Ibu Hamil Tentang Kehamilan}

Pengetahuan ibu hamil tentang kehamilan pada umumnya masih kurang $(68,51 \%)$ dan yang berpengetahuan baik hanya 4 orang $(7,41 \%)$. Pengetahuan ibu hamil yang kurang inilah kemungkinan masih dipercayainya berbagai hal yang menyangkut tentang larangan/pantangan makanan ataupun melakukan suatu tindakan/ aktivitas (pantangan perilaku).

Fauzia dalam penelitiannya tentang mitos kehamilan mengungkapkan bahwa pengetahuan bersumber dari dua bagian yaitu pertama dari kesehatan modern yang berupa konsultasi atau anjuran dari dokter dan bidan. Sedangkan penge tahuan tradisional berupa kepercayaan terhadap berbagai pantangan dan anjuran selama kehamilan. Hal ini dipengaruhi oleh semakin berkembangnya pengetahuan dan informasi dari masyarakat yang semakin hari semakin modern. Meskipun demikian, pengetahuan tradisional tidak sepenuhnya ditinggalkan masyarakat dengan alasan terjalin hubungan yang erat dalam komunitas sosial sehingga kebiasaan yang melingkupi tempat tinggal masyarakat akan mempengaruhu sikap dan perilakunya.

\section{KESIMPULAN DAN SARAN}

\section{Kesimpulan}

1. Interaksi Berdasarkan hasil penelitian di tinjau dari segi sosial ibu hamil pada umumnya ibu hamil berinteraksi dengan suami dan tetangga $(100 \%)$,dengan orang tua $(27,77 \%)$,dengan mertua $(12,96 \%)$,dengan bidan $(11,11 \%)$ dan sesama ibu hamil $(9,25 \%)$.Interaksi Ibu hamil saat ada keluhan memiliki persentase dengan suami(100\%),orang tua( $18,51 \%)$,mertua dan tetangga $(9,25 \%)$ dan bidan $(12,96 \%)$,interaksi terdekat ibu hamil dengan suami $(100 \%)$,orang tua $(22,22 \%)$,dengan mertua dan bidan $(5,55 \%)$.Untuk sumber nasehat saat hamil bersumber dari mertua $(62,96 \%)$,orag tua $(53,70 \%)$ dan tetangga $(37,03 \%)$.

2. Dlihat dari segi budaya bahwa pada umumnya ibu hamil masih memiliki kepercayaan tentang berpantang makan, perilaku, mengikuti nasehat pantangan ataupun anjuran saat hamil dan masih melaksanakan upacara kehamilan.

3. Berdasarkan pengetahuan ibu hamil, ibu hamil berpengetahuan baik sebanyak 4 orang $(7,41 \%)$, ibu hamil berpengetahuan cukup $13(24,08 \%)$ dan ibu 
hamil berpengetahuan kurang 37 (68,51\%).

\section{Saran}

1. Penelitian ini perlu dilanjutkan untuk melihat faktor yang mempengaruhi sosial budaya tentang kehamilan dimasyarakat.

2. Dalam penelitian ini data/kuesioner hanya diperoleh dari ibu hamil. Data dari lingkungan sekitar ibu seperti suami, mertua ataupun orang tua perlu dikaji lebih lanjut.

\section{DAFTAR PUSTAKA}

Almatsier S, 2009, Konsep Dasar Ilmu Gizi, PT Gramedia Utama, Jakarta

Ana,S.2010,Trimester Pertama Kehamilan Anda,Bukubiru, Yogyakarta

Dinas Kesehatan Kota Binjai, 2012, Buku Kesehatan Ibu dan Anak. Departemen Kesehatan RI, Jakarta.

Eva dkk, 2010 , Kesehatan Reproduksi Wanita ,Trans Info Media, Jakarta.

Fauziah,2008, Mitos - mitos Tentang Kehamilan,Jurnal Kesehatan

Indonesia,2729072009_20.pdf(SECURED), di akses tanggal 5 Mei 2014

Hesty dkk, Konsep Perawatan Kehamilan Etnis Bugis Pada Ibu Hamil Di Desa Buareng Kecamatan Kajuara Kabupaten Bone, 2013, jurnal penelitian , di akses tanggal 20 januari 2014

Wahit dkk, 2012 , Ilmu Sosial Budaya Dasar kebidanan, EGC ,Jakarta.

Notoadmojo, S, 2010, Metodologi Penelitian Kesehatan, Rieneke Puspita,Jakarta

Maryunani,A dkk 2012,Asuhan Kegawatdaruratan Dalam Kebidanan,Trans Info Media,Jakarta

Profil Kesehatan Indonesia, 2011, Cakupan Kunjungan Ibu Hamil K1, K4 Sumatera Utara ,Kementerian Kesehatan RI Tahun 2012, Jakarta.
Rahim Muarifah dkk,Gambaran Perilaku Ibu Hamil Terhadap Pantangan Makan Suku Toraja Di Kota Makassar, 2013, Jurnal penelitian, repository.unhas.ac.id/bitstream/handle/.../jurnal.p df di akses tanggal 15.januari 2014

Rafael, 2007, Manusia dan kebudayaan Dalam Perspektif Ilmu Budaya Dasar,Rineka Cipta,Jakarta

Rafie, 2009, Menjawab Mitos - Mitos Kehamilan Dan Menyusui, Media Pressindo,Yogyakarta

Ronald, 2010,Pedoman dan Perawatan kehamilan Yang Sehat dan Menyenangkan, Nuansa Aulia, Bandung

Suryawati,C ,2007,Faktor Sosial Budaya dalam Praktik Perawatan Kehamilan,Persalinan dan Pasca Persalinan(Studi di Kecamatan Bangsari Jepara), Jurnal Promosi Kesehatan Indonesia Vol 2 Mei 2014.

Shrimarti,R,2011,Perawatan Kehamilan dalam Perspektif Budaya Madura di Desa Tambak dan Desa Rapalaok Kecamatan Omben Kabupaten Sampang ,di akses tanggal 2 mei 2014

Tari Romana, 2012, Mengenal Tradisi Nusantara Seputar Kehamilan,

http://health.kompas.com/read/2012/09/10/151455

33/Mengenal.Tradisi. $\mathrm{N}$ usantara.Seputar.Kehamilan) di akses tanggal 15 januari 2014

Wahyuna,F,2013 ,Gambaran Sosial Budaya Dengan Pola Makan Ibu Hamil Di Kemukiman Jangka Buya Kecamatan Jangka Buya Kabupaten Pidie Jaya Tahun 2013.Jurnal Karya Tulis ilmiah.Fitri_Wahyuna-Jurnal .pdf.di akses tanggal 26 Maret 2014.

Wahit dkk, 2012 , Ilmu Sosial Budaya Dasar kebidanan, EGC, Jakarta. 